\title{
JUNGLE TALES OF A GRANDFATHER
}

\author{
By P. M. Lushington \\ (Continued)
}

\section{No. 2. My Lord the Elephant}

I could fill a book with stories about that dear fellow, the Indian elephant, had he not been immortalized by Rudyard Kipling's famous story of that little upstart "Toomai". The Times has also written about him, and Mr. Craven Hill, F.Z.S., has told stories of his sense of fun.

I will therefore confine myself to family stories, the first about my own daughter of about 3 years old, and the second about Ceylon elephants, sent to me by my nephew, C. F. Lushington. Wherever vernacular appears it is spelt phonetically.

When we were living in Nilambur my daughter, about $\mathbf{3}$ years old, used often to be wheeled down the hill in a small chair by an excellent ayah, very small in stature, to a shady spot close to the main road to partake of their chota-harzri. On one occasion a big tusker came walking along the road, unattended by his mahout. "Ibberd-Arn" squealed the small girl, and obediently the elephant came to her wagging his trunk. They looked in their basket and found only a small piece of bread and butter and a plantain (banana), and there he stood saying "Thank you " with his upturned trunk and would not go away because they did not know the word of command, "UbberdArn." And in this case it was the animal who showed loving kindness, because he did not trample on them with one step forward. But they were very thankful when the mahout turned up and put an end to their anxiety.

This is what my nephew tells me about the tame elephants in Ceylon :-

"Amongst the well-trained tame elephants it is interesting to watch them thinning out the marked rubber trees (poor yielders about 2 feet in girth). They press their heads firmly against the tree until it is leaning about 45 degrees or so. They then put the weight of a heavy forefoot on it and finally turn round and haul up the tap-root, if they can, like a giant carrot, before passing on to the next tree to be dealt with, doing the work of about 100 coolies in a day."

If a bulldozer can do as good work, and keep it up for 40 years, I shall begin to think the elephant may be out of date.

To end my note on the elephant I quote another story from my nephew's letter :- 
"You have heard of a 'bull in a china shop', but it isn't everybody who has had the fun of seeing a baby elephant pursuing his empty bottle of milk into the drawing room, without knocking over a thing - well I have."

\section{No. 3. The Little Black Bear}

Before I went to India I heard the story that my brother Alfred had been badly mauled by a black bear, and not much else was said on the subject, as my father evidently wanted to keep it quiet. I pictured to myself a big black fellow who would get on his hind legs and open his arms to cuddle you. When I got to my first district, Kurnool, and was engaged in reconstructing fuel stacks, a little black fellow tumbled on to the railway line. I took him to be a cub, but the Chenchus knew better and told me he was the most dangerous beast in the jungle. In less than a month I knew him well, and he seemed to be in the habit of popping up, and no Indian had a good word to say for him.

Later on in my service I found him in every district in Madras, always tumbling into a road. Several times he has looked at me and more than once $I$ have pointed my gun, but never fired at him. On the Burghur Ghat I think he must have made his principal home for he was constanty waddling on to the road at every mile. Once when $I$ was camping at Hassanur I decided to pitch a tent in a valley 7 or 8 miles away. I had never been there before and I found it a beautiful place, but warm considering it was over 3,000 feet up. I dined in the veranda and soon became aware that the valley was full of game as I heard the humph-humph of the tiger, the screech of the jackals, and the yowl of the hyena. So I slept in the tent with the front door open and the bathroom flap tied up. I was soon asleep but at about 3 a.m. there was a crash, and the lamp on a chair by the side of my bed tumbled over and went out. I knew therc was an animal in the tent, and put out my arm to get my gun. I suddenly found that I had placed my hand on a warm fleecy back, which emitted a sort of grunt, seeming to show he was as startled as I was. Very soon he was out of the door, and I realized that I had stroked the little black bear! I have often wondered since that date whether this truculent little beast has ever been tamed by loving kindness and allowed to appear in the " Mappin Gallery" with the rest of that jovial society. I should doubt it. 